\title{
Status and Interrelation of Trace Minerals and Steroid Hormones in Heifers
}

\author{
Mohd. Iobal Yatoo ${ }^{*}$, Archana Saxena ${ }^{2}$, Arumugam Gopalakrishnan ${ }^{1}$, Sampath Kumar \\ Santhosh Kumar ${ }^{3}$, Vasudevan Sujatha ${ }^{4}$, Murugan Shanmugam Murugan ${ }^{5}$, Mahesh Chandra \\ SHARMA ${ }^{1}$
}

${ }^{1}$ Division of Medicine, ICAR-Indian Veterinary Research Institute, Izatnagar, Barielly-243122, Uttar Pradesh, India; ${ }^{2}$ Division of Molecular Bioprospection, CSIR-Central Institute of Medicinal and Aromatic Plants, Lucknow-226015, Uttar Pradesh, India; ${ }^{3}$ Veterinary Dispensary, Edaiyur, Thiruthuraipoondi, Thiruvarur-614702, Tamil Nadu, India; ${ }^{4}$ Education Cell, Madras Veterinary College, Chennai-600006, Tamil Nadu, India; ${ }^{5}$ Assistant Professor, Department of Veterinary Microbiology, Veterinary College and Research Institute, Ramayanpatti, Tirunelveli-627358, Tamil Nadu, India.

\begin{abstract}
The aim of the present study was to evaluate the serum trace mineral and steroid hormone status in heifers and to find interrelation among them. Thirty crossbred heifers (Holstein Friesen X local non-descript) were divided into three groups on the basis of age viz. group A (12-18 months), group B (18-24 months) and group C (24-30 months) and each group was having ten animals $(n=10)$ each. Serum trace minerals were estimated by atomic absorption spectrophotometry and steroid hormones (estrogen and progesterone) by radio immuno assay. Overall mean $\pm \mathrm{SE}$ of copper, iron, zinc and manganese in heifers was found to be $0.59 \pm 0.20,1.32 \pm 0.57,0.93 \pm 0.38$ and $0.18 \pm 0.03$ ppm respectively. Most of the trace minerals were in deficient range when compared with critical levels. Overall mean $\pm \mathrm{SE}$ of estrogen and progesterone in heifers was $18.34 \pm 2.28 \mathrm{pg} / \mathrm{mL}$ and $0.83 \pm 0.21 \mathrm{ng} / \mathrm{mL}$ respectively. Copper showed non-significant $(\mathrm{p} \geq 0.05)$ decrease whereas iron showed non-significant $(p \geq 0.05)$ increase with increase in age. Zinc and manganese showed significant $(\mathrm{p}<0.05)$ decrease with age. Serum estrogen significantly $(\mathrm{p}<0.05)$ increased with increase in age whereas serum progesterone decreased non-significantly $(p \geq 0.05)$ with increase in age. Positive and significant $(p<0.05)$ correlations were noted between most of the trace minerals and steroid hormones. This may be due to involvement of trace minerals in steroid hormone synthesis through metalloenzymes or cofactors. Hence supplementation of trace minerals can improve animal health and reproductive efficiency by minimizing mineral deficiency and favouring steroid hormone synthesis.
\end{abstract}

Keywords | Heifer, Steroid hormone, Trace mineral

\footnotetext{
Editor $\mid$ M. Saminathan (M.V.Sc), Division of Pathology, ICAR-Indian Veterinary Research Institute (ICAR-IVRI), Izatnagar, Bareilly, Uttar Pradesh, India Special Issue | 2, 2016 "Emerging Challenges and Opportunities in Veterinary Research for Improvement of Animal Health".

Received | November 27, 2015; Revised | February 01, 2016; Accepted | February 03, 2016; Published | March 06, 2016

*Correspondence | Dr. Mohd. Iqbal Yatoo, ICAR-Indian Veterinary Research Institute, Izatnagar, Bareilly-243122, Uttar Pradesh, India; Email: iqbalyatoo@ gmail.com

Citation | Yatoo MI, Saxena A, Gopalkrishnan A, Kumar SS, Sujatha V, Murugan MS, Sharma MC (2016). Status and interrelation of trace minerals and steroid hormones in heifers. Adv. Anim. Vet. Sci. 4(2s): 1-4.

DOI | http://dx.doi.org/10.14737/journal.aavs/2016/4.2s.1.4

ISSN (Online) | 2307-8316; ISSN (Print) | 2309-3331
}

Copyright $(\odot 2016$ Yatoo et al. This is an open access article distributed under the Creative Commons Attribution License, which permits unrestricted use, distribution, and reproduction in any medium, provided the original work is properly cited.

\section{INTRODUCTION}

$\mathrm{T}$ race minerals are essential for proper functioning of number of enzymes and proteins (Spears, 2003; Gressley, 2009) involved in many biological processes including hormone synthesis (Smith et al., 2000). These hormones are involved in different developmental processes including growth and reproduction. Hence deficiency of trace minerals affects hormone production and accord- ingly productive and reproductive performance is affected (Sharma and Joshi, 2005; Ceylan et al., 2008). Young growing heifers are particularly at risk of deficiency as body demands are increasing and developmental processes are changing from growth to reproductive phase (NRC, 2003), necessitating an adequate supply of trace minerals for proper reproductive efficiency. Trace mineral deficiency has been cited as one of the major causes of poor performance both in health and reproduction in many tropical 
countries (McDowell et al., 1984; Sharma et al., 2003). For this purpose the present study was under taken to evaluate the trace mineral status and their interrelation with steroid hormones in growing heifers so that the requirement for mineral supplementation in the diet, if any, can be evaluated.

\section{MATERIALS AND METHODS}

A total of thirty crossbred heifers (Holstein Friesen X local non-descript) were selected randomly from farmers herd in Kashmir Valley and were divided into three groups on the basis of age viz. group A (12-18 months), group B (1824 months) and group $\mathrm{C}$ (24-30 months). Each group was having ten animals $(\mathrm{n}=10)$. Blood samples $(10 \mathrm{~mL})$ were collected by jugular vein puncture into vials without anticoagulant and serum was harvested. Serum trace minerals were estimated by atomic absorption spectrophotometry after digesting the serum samples by the procedure of Kolmer et al. (1951). Serum estrogen $\left(E_{2}\right)$ and progesterone $\left(\mathrm{P}_{4}\right)$ were determined by radioimmunoassay (RIA) technique using gamma scintillation counter ( $\mathrm{I}^{125}$ calibrated), at Nuclear Research Laboratory, Division of Physiology and Climatology, IVRI, Izatnagar. Estradiol radioimmuno assay kits were obtained from Immunotech, France whereas progesterone radioimmunoassay kit was obtained from Bhabha Atomic Research Centre (BARC), Mumbai, India. Data were analyzed as per the method described by Snedecor and Cochran (1994) for mean, standard error, correlation and analysis of variance (ANOVA).

Table 1: Mean $\pm \mathrm{SE}$ of trace minerals in heifers

$\begin{array}{lllll}\text { Group } & \text { Copper } & \text { Iron } & \text { Zinc } & \text { Manganese } \\ \text { Group A } & 0.58 & 1.25 & 0.91 & 0.19 \pm 0.05 \\ \begin{array}{l}(12-18 \text { months) } \\ \text { N=10 }\end{array} & \pm 0.18 & \pm 0.53 & \pm 0.38 & \\ \text { Group B } & 0.59 & 1.43 & 0.89 & 0.17 \pm 0.04 \\ \text { (18-24 months) } & \pm 0.23 & \pm 0.61 & \pm 0.41 & \\ \text { N=10 } & & & & \\ \text { Group C } & 0.57 & 1.41 & 0.86 & 0.16 \pm 0.02^{*} \\ \text { (24-30 months) } & \pm 0.16 & \pm 0.58 & \pm 0.34^{*} & \\ \text { N=10 } & & & & \\ \text { Over all } & 0.59 & 1.32 & 0.93 & 0.18 \pm 0.03 \\ & \pm 0.20 & \pm 0.57 & \pm 0.38 & \end{array}$

*Values with different superscript differ significantly $(\mathrm{p}<0.05)$ in a column.

\section{RESULTS}

Mean \pm SE of trace minerals are given in Table 1. Lower levels of copper and iron were noted in group A and $\mathrm{C}$ heifers than the group B heifers. Lower levels of zinc and manganese were observed in group $\mathrm{B}$ and $\mathrm{C}$ heifers than the group A heifers. Copper showed non-significant $(p \geq 0.05)$ decrease whereas iron showed non-significant $(p \geq 0.05)$ increase with increase in age. Zinc and manganese levels showed significant $(p<0.05)$ decrease with increase in age. Copper and iron showed non-significant $(p \geq 0.05)$ difference between different age groups whereas zinc and manganese showed significant difference between group A and group $\mathrm{C}$ heifers. Mean $\pm \mathrm{SE}$ of hormones are given in Table 2. Serum estrogen significantly $(\mathrm{p}<0.05)$ increased with increase in age whereas serum progesterone showed non-significant $(p \geq 0.05)$ decrease with increase in age.

Table 2: Mean $\pm \mathrm{SE}$ of hormones in heifers

$\begin{array}{lll}\text { Group } & \begin{array}{l}\text { Estrogen } \\ (\mathbf{p g} / \mathbf{m L})\end{array} & \begin{array}{l}\text { Progesterone } \\ (\mathbf{n g} / \mathbf{m L})\end{array} \\ \begin{array}{l}\text { Group A (12-18 months) } \\ \mathrm{N}=10\end{array} & 16.37 \pm 1.27 & 0.82 \pm 0.12 \\ \begin{array}{l}\text { Group B (18-24 months) } \\ \mathrm{N}=10\end{array} & 18.82 \pm 2.49 & 0.80 \pm 0.18 \\ \begin{array}{l}\text { Group C (24-30 months) } \\ \mathrm{N}=10\end{array} & 19.92 \pm 3.21^{*} & 0.77 \pm 0.22 \\ \text { Over all } & 18.34 \pm 2.28 & 0.83 \pm 0.21\end{array}$

*Values with different superscript differ significantly $(p<0.05)$ in a column.

Positive and significant $(\mathrm{p}<0.05)$ correlation was noticed between copper (0.55), zinc (0.60), manganese (0.58) and estrogen whereas iron (0.47) showed positive but non-significant $(p \geq 0.05)$ correlation. Similarly copper $(0.52)$ and manganese $(0.54)$ showed positive and significant $(\mathrm{p}<0.05)$ with progesterone whereas iron (0.36) showed positive but non-significant $(\mathrm{p} \geq 0.05)$ correlation and zinc $(-0.33)$ showed negative and non-significant $(\mathrm{p} \geq 0.05)$ correlation.

\section{DISCUSSION}

Lower level of copper and iron observed in group A may be due to the lower level of these minerals in milk ( $\mathrm{Ra}^{-}$ dostitis et al., 2007) which constitutes the main diet of young animals. Higher levels of iron in group B and C heifers may be due to the presence of adequate amount of iron in fodders (Yatoo et al., 2011). Lower levels of copper, zinc and manganese in group $\mathrm{C}$ heifers may be due to the deficiency of these trace minerals in fodders (Yatoo et al., 2013). Lower levels of trace minerals in group $C$ heifers may also be due to the increase in requirements of the trace minerals with increasing age for different developmental processes (NRC, 2001) including reproductive development and hormone synthesis (Smith et al., 2000).

Table 3: Correlation coefficient of trace minerals and steroid hormones

$\begin{array}{lllll} & \text { Copper } & \text { Iron } & \text { Zinc } & \text { Manganese } \\ \text { Estrogen } & 0.55^{*} & 0.47 & 0.60^{*} & 0.58^{*} \\ \text { Progesterone } & 0.52^{*} & 0.36 & -0.33 & 0.54^{*}\end{array}$

* Significant correlation $(\mathrm{p}<0.05)$. 
Increase in estrogen with age of heifers may be due to activation of reproductive organs or processes in which trace minerals play an important role (Boland, 2003; Ceylan et al., 2008). Decrease in progesterone levels may be due to inhibitory effect of estrogen on progesterone along with increased release of estrogen in adult heifers. Trace minerals play a vital role in estrogen and progesterone synthesis and production. Copper and zinc are involved in regulating progesterone production by luteal cells via involvement of superoxide dismutase (Sugino et al., 1999). Zinc is a component of insulin like growth factors involved in regulation of granulosa cell estradiol production during follicular waves in cattle (Kobayashi et al., 2006). Manganese acts as a cofactor in the synthesis of cholesterol which is precursor of steroids like estrogen and progesterone (Nocek et al., 2006). Correlation between iron and progesterone can be attributed to its role in ovarian activity (Qian et al., 2001).

Copper, zinc and manganese levels followed same trend as estrogen levels with variation in age suggesting positive interrelation as reflected from positive and significant $(p<0.05)$ correlation. But mere positive and significant correlation cannot interpret the importance of this interrelation because of involvement of many enzyme systems in hormone regulation. As in case of zinc, iron and progesterone though the correlation was either negative or non-significant but the role of zinc and iron in progesterone production or ovarian function is well reported (Sugino et al., 1999; Qian et al., 2001).

From the present study it can be inferred that trace minerals and steroid hormone have important interrelation. Deficiency of former can affect latter and consequently reproductive performance of animals especially in heifers. Hence maintenance of appropriate serum mineral levels by proper supplementation can boost production and reproductive performance.

\section{ACKNOWLEDGMENT}

Authors are thankful to Director Indian Veterinary Research Institute for their kind support in this research.

\section{CONFLICT OF INTEREST}

Authors declare that they have no conflict of interest.

\section{AUTHOR'S CONTRIBUTION}

Mohd. Iqbal Yatoo drafted manuscript and analysed data, Archana Saxena edited manuscript, Gopala KrIhsnan edited manuscript and revised it, S Santhosh Kuamr edited manuscript, V Sujatha edited manuscript, MS Muruagn edited manuscript, Mahesh Chander Sharma provided guidance.

\section{REFERENCES}

-Boland MP (2003). Trace minerals in production and reproduction in dairy cows. Adv. Dairy Technol. 15: 319330.

-Ceylan A, Serin Ý, Aksit H, Seyrek K (2008). Concentrations of some elements in dairy cows with reproductive disorders. Bull Vet. Inst. Pulawy. 52: 109-112.

-Gressley T (2009). Zinc, Copper, Manganese, and Selenium in dairy cattle rations. Proceedings of the $7^{\text {th }}$ Annual MidAtlantic Nutrition Conference. Pp. 65-71.

-Kobayashi Y, Jimenez-Krassel F, Ireland JJ, Smith GW (2006) Evidence of a local negative role for cocaine and amphetamine regulated transcript (CART), inhibins and low molecular weight insulin like growth factor binding proteins in regulation of granulosa cell estradiol production during follicular waves in cattle. Reprod. Biol. Endo. 4: 22 http://dx.doi.org/10.1186/1477-7827-4-22

-Kolmer JA, Spanbling EH, Robinson HW (1951). Approved Laboratory Technique. Appleton Century Crofts, New York.

-McDowell LR, Conrad JH, Ellis GL (1984). Mineral deficiencies and imbalances and their diagnosis. In: Symposium on Herbivore Nutrition in Sub-Tropics and Tropics-Problems and Prospects (Editors: F.M.C. Gilchrist and R.I. Mackie) Pretoria, South Africa. Pp. 67-88.

-Nocek JE, Socha MT, TomLinson DJ (2006) The effect of trace mineral fortification level and source on performance of dairy cattle. J. Dairy Sci. 89: 2679-2693 http://dx.doi. org/10.3168/jds.S0022-0302(06)72344-X

-NRC (2001). Nutrient Requirement of Domestic Animals. Nutrient Requirements of Dairy cattle. 7th Rev. Ed. National Academy of Science, National Research Council, Washington, D.C.

-NRC (2003). Nutrient Requirements of Dairy Cattle. 2nd Revised Ed. National Academy of Science, National Research Council, Washington, D.C.

-Qian LC, Zou XT, Xu ZR, Xi S (2001). Effect of various levels of iron on the reproductive performance and biochemical parameters of gestation cow. Chinese J. Vet. Sci. 21: 526-528.

-Radostits OM, Gay CC, Constable PD, Hinchcliff KW (2007). A textbook of the diseases of cattle, sheep, pigs, goats and horses $10^{\text {th }}$ edn, W B Saunders Co, Philadelphia.

-Sharma MC, Raju S, Joshi C, Kaur H, Varshney VP (2003). Studies on serum micromineral, hormone and vitamin profile and buffaloes, its effect on production and therapeutic management in Haryana state of India. Asian Australasian J. Anim. Sci. 6(4): 519-528. http://dx.doi.org/10.5713/ ajas.2003.519

-Smith OB, Akinbomiju OO, Forsberg M, Grove T, Gustufsson H, Kafila T, Kindahi H, Ropstad E (2000). Micronutrients and reproduction in farm animals. Ani. Rep. Sci. 61: 549560. http://dx.doi.org/10.1016/S0378-4320(00)00114-7

-Snedecor GW, Cochran WG (1994). Statistical Methods. $6^{\text {th }}$ Edn. Iowa State University Press. Ames, Iowa.

- Spears JW (2003). Trace Mineral Bioavailability in Ruminants. J. Nutr. 133: 1506-1509.

-Sugino N, Takiguchi S, Kashida S, Takayama HY, Nakamura Y, Kato H (1999). Suppression of intracellular sod activity by antisense oligonucleotide causes inhibition of progesterone production by rat luteal cells. Biol. Rep. 61: 1133-1138. http://dx.doi.org/10.1095/biolreprod61.4.1133

-Yatoo MI, Dimri U, Sharma MC (2013). Status of micro mineral deficiency in cattle in Kashmir valley. J. Anim. Health Prod. 
Advances in Animal and Veterinary Sciences 1(3): $24-28$.

plant animal micro mineral status and their inter relation in

- Yatoo MI, Devi S, Kumar P, Tiwari R, Sharma MC (2011). Soil Kashmir valley. Indian J. Anim. Sci. 81(6): 628-630.

May 2016 | Volume 4 | Special issue 2 | Page 4 